\title{
Simultaneous generation of longitudinal and shear ultrasonic waves: knowledge summary, PZT piezoelements manufacturing and experiments
}

\author{
A. Voleišis, R. Kažys, B. Voleišienė, R. Šliteris \\ Ultrasound Institute, Kaunas University of Technology, \\ Studentu 50, LT-51368 Kaunas, Lithuania, \\ Phone: +370 37 351162, Fax. +370 37451489 \\ E-mail :algirdas.voleisis@ktu.lt
}

\begin{abstract}
Known ultrasonic transducers for simultaneous generation of longitudinal and shear waves are reviewed: quartz and lithium niobate crystals tilted $\mathrm{CdS}$ and $\mathrm{ZnO}$ films. A special attention is devoted to the rotated cuts of PZT piezoceramics, literature data theoretical background conclusions are analysed. Manufacturing technology of dual mode PZT transducers with different cut angles and thickness was developed. Reliable electrodes suitable for soldering are made chemically in electroless nickel (EN) plating bath. Nickel electrodes are additionally dectroplated with silver. Various types of PZT ceramics were successfully used. From impedance measurements longitudinal and shear resonances were determined for typical thicknesses $45-100 \mu \mathrm{m}$. The cut angle $36^{\circ}$ for equal efficiency of both waves was experimentally determined. Operation of transducers soldered to the steel rods and measurement bodies of the certain geometry was investigated. Measurements were provided in a temperature range $20-160{ }^{\circ} \mathrm{C}$. Axial load experiments up to $234 \mathrm{MPa}$ were provided and corresponding linear dependencies were determined. Experiments showed good performance of developed dual mode PZT ultrasonic transducers.
\end{abstract}

Keywords: dual mode, longitudinal and shear wave simultaneous generation, ultrasonic transducers.

\section{Introduction}

Ultrasonic transducers are usually intended for generation and reception of only longitudinal $(L)$ or shear (S) waves. Very often ultrasonic non-destructive testing (NDT) and evaluation (NDE) requires measurements of both longitudinal $(L)$ and shear $(S)$ waves in a medium. Thus ultrasonic transducers which generate both $L$ and $S$ waves simultaneously are requested. For example, reliable determination of axial loads and preloads of screws in structural parts can be provided by measuring delays of both $L$ and $S$ waves along the screws direction [1].

Historically, various cuts of quartz crystals (AT, SC, BT, IT, AK) operating in a thickness-shear mode were known first. Various cuts were found for highly stable oscillators, SAW devices, temperature sensors, etc. [2].

Thickness-shear mode (TSM) resonators have been successfully used to characterize static rheological properties of plasma and whole blood samples, including blood coagulation tracking throughout the entire process [3].

Nowadays, quartz crystal piezoelements are used less in ultrasonics, as better piezomaterials are accessible.

\section{Lithium niobate crystals}

Both $L$ and $S$ waves can be generated simultaneously and efficiently using $10^{\circ}$ rotated Y-cut lithium niobate piezoelements. They are offered commercially by Boston Piezo-Optics Inc. as "Tripple-Mode Transducer Crystals" (longitudinal+shear+dual) [4]. The third harmonic of the longitudinal mode coincides with the fifth harmonic of the shear mode. For example, a crystal with a thickness $0.684 \mathrm{~mm}$ will oscillate at its fundamental longitudinal mode of $f_{\mathrm{L}}=5.0 \mathrm{MHz}$, its fundamental shear mode $f_{\mathrm{S}}=3.0 \mathrm{MHz}$ and its dual mode frequency is $f_{\mathrm{D}}=15 \mathrm{MHz}$.
The 22 crystals are available with $f_{\mathrm{L}}=1 \div 31.7 \mathrm{MHz}$, $f_{\mathrm{S}}=0.6 \div 19.0 \mathrm{MHz}$; thus $f_{\mathrm{D}}=3.0 \div 95 \mathrm{MHz}$.

As seen, in dual mode piezoelements $f_{\mathrm{L}}>f_{\mathrm{S}}$. It is due to the fact, that always, including piezomaterial, ultrasound velocity of $L$ wave is larger than velocity of $S$ wave, i.e. $c_{\mathrm{L}}>c_{\mathrm{S}}$.

\section{Tilted CdS and ZnO films}

A separate group of dual mode ultrasonic transducers compile artificially made $\mathrm{CdS}$ and $\mathrm{ZnO}$ films [5-10]. In thick CdS films with low disorientation the longitudinal mode $L$ is easily excited. In this case $C$ axis of the CdS crystal is perpendicular to the sample surface, $\Theta \sim 0^{\circ}$. $S$ mode requires $\Theta=90^{\circ}$, this corresponds to surface excitation, which possible only theoretically. The requirement $\Theta>90^{\circ}$ may be achieved the tilting the sample with respect to the mean direction of the CdS beam during the vacuum deposition of the piezoelectric layer. In [10] CdS experimental results are reported. Thick 40$50 \mu \mathrm{m}$ disorientated layers operated in a dual $L / S$ mode in the frequency range $50-100 \mathrm{MHz}$. $L$ and $S$ echo patterns were observed on $\mathrm{Al}_{2} \mathrm{O}_{3}$ single-crystal substrate.

For high-frequency ultrasonic applications $\mathrm{ZnO}$ piezoelectric film transducers are widely used and most studied. It is well known that $\mathrm{ZnO}$ film with $C$ axis (crystalline $Z$ axis) normal to the substrate surface can excite longitudinal waves. Shear waves are excited if $C$ axis is $41^{\circ}$ tilted. At the $16^{\circ}$ tilted angle $L$ and $S$ modes are almost equal [5]. Experiments described in this article were performed also with a $60^{\circ}$ tilted $\mathrm{ZnO}$ thin film, $L / S$ pulse echo trains were observed in a fused quartz substrate at frequencies 350 - $510 \mathrm{MHz}$.

As $\mathrm{ZnO}$ films can operate in the dual $L / S$ mode, alternative experiments are known with the goal to produce ultrasonic transducers with a pure longitudinal wave for 
ultrasonic microscopes and other imaging systems at frequencies greater than $100 \mathrm{MHz}$. The same reason concerns AlN films [9].

Simultaneous generation of longitudinal and shear bulk ultrasonic waves in solids was investigated in [6, 7]. It is emphasized that in the $50 \mathrm{MHz}-1 \mathrm{GHz}$ frequency range $\mathrm{LiNbO}_{3}$ (in the form of platelets bonded onto the substrate, lapped to the desired thickness and then polished) and $\mathrm{CdS}$ or $\mathrm{ZnO}$ (in the form of evaporated and deposited layers) are the most often used piezoelectric transducer materials. Simultaneous generation of longitudinal and shear bulk waves is possible when using $Y$-cuts rotated at the angle $\Theta$ with respect to the $X$ crystallographic axis. Transducer configurations comprising a single transducer or two transducers (the same piezoelectric material with different cuts or different piezoelectric materials) are analyzed. In a single layer transducer, when the cut angle $\Theta$ varies with respect to the $X$-axis, the wave velocities (and thus the thickness required for operating at a given frequency) vary. An innovative two-layer transducer solution was investigated. A systematic study was performed using nine combinations available with the choice between $\mathrm{CdS}, \mathrm{ZnO}$ and $\mathrm{LiNbO}_{3}$ for both the first and the second piezoelectric layers. Several solutions have been found for efficient wideband generation of the $L$ and $S$ modes.

Thin films stack transducer for simultaneous generation of longitudinal and shear waves at the same frequency is proposed and investigated in [11]. Earlier simultaneous generation of both waves at the same frequency has not been achieved, because extensional mode and the thickness shear mode of the piezoelectric layer are different. The stack transducer consists of twolayered $C$-axis tilted $\mathrm{ZnO}$ film. The upper and the lower layers have the same thickness, and $C$-axis tilt direction in both layers is symmetric with respect to the surface normal. In this structure, a thickness extensional mode is excited as the fundamental mode, whereas a thickness shear mode is excited as the second overtone mode. At the $C$-axis tilt angle of $23^{\circ}$, the quasi-longitudinal wave velocity of $6136 \mathrm{~m} / \mathrm{s}$ is exactly twice the quasi-shear wave velocity of $3068 \mathrm{~m} / \mathrm{s}$, thus both waves can be generated efficiently at the same frequency. It is declared, that both modes have high electromechanical coupling coefficients: $k_{33}^{\prime}=0.20, k_{15}^{\prime}=0.38$. This thin film stack transducer was made on a silica glass substrate, $L$ - and $S$-waves were successfully excited at adjacent frequencies $f_{\mathrm{L}}=278 \mathrm{MHz}$, $f_{\mathrm{S}}=266 \mathrm{MHz}$ with a high efficiency.

\section{Other methods}

Laser generation and detection of longitudinal and shear waves in a diamond anvil cell was investigated in [12]. Acoustic waves were excited with "pump" laser (neodymium doped yttrium aluminium garnet laser, $100 \mathrm{mV}$ power at $1064 \mathrm{~nm}, 0.5 \mathrm{~ns}$ pulse at $20 \mathrm{kHz}$ repetition frequency). For detection of acoustic waves "a probe" laser was necessary ("Compass" laser with a power $150 \mathrm{mV}$ at $523 \mathrm{~nm}$ ). Longitudinal and shear waves were detected and their velocities were measured at pressures up to $23 \mathrm{GPa}$.

A simple solution for generation of $L$ and $S$ waves in a low $\mathrm{MHz}$ frequency range is published in [13]. In apparatus for simultaneous determination of longitudinal and shear wave velocities in rocks under pressure ultrasonic transducer is a sandwich of two crystals, one (inner) generating longitudinal waves and one (upper) generating shear waves.

\section{Mode conversion}

Extensive investigations in the field of hightemperature integrated ultrasonic shear and longitudinal wave probes are known [1, 14-18]. In these metallic (aluminium) probes shear waves are generated due to mode conversion from longitudinal to shear waves because of reflection inside the metallic substrate having a specific shape ( $64.6^{\circ}$ angle). In the case of a mild steel probe, this angle is equal $61.5^{\circ}$ ). An additional $45^{\circ}$ angle plane with respect to the $L$ wave ultrasonic transducer was machined onto the $S$ wave probe. Thus one half of the ultrasonic beam from the transducer is used at the $64.6^{\circ}$ plane for mode conversion from $L$ to $S$ waves, the second half of this beam ( $L$ waves) only changes direction at the $45^{\circ}$ plane. In this probe both $S$ and $L$ beams propagate parallel, to each other, but not along the same path. With a high temperature piezoelectric film with a PZT composite attached onto the substrate by a paint-on method these probes successfully operated up to $150^{\circ} \mathrm{C}$. When bismuth titanate powders instead of PZT powders as a piezoelectric material were used, a good signal to noise ratio $\mathrm{S} / \mathrm{N}$ has been obtained at $350^{\circ} \mathrm{C}$.

The same idea of mode conversion was used by same authors in making screws as axial load and temperature probes using an integrated ultrasonic transducer $[2,17]$. In order to propagate $L$ wave along the axial direction of the screw back and forth a $45^{\circ}$ reflection (steel/air) was used. $L$ to $S$ mode conversion is observed at the $61.4^{\circ}$ reflection angle. This angle is chosen so that the mode converted $\mathrm{S}$ wave will propagate back and forth along the axial direction. The ultrasonic transducer was fabricated directly onto the lateral surface of the head of the screw by the solgel sprayed method. $45^{\circ}$ and $61.4^{\circ}$ reflection surfaces were machined from the head of the screw. In this experiment $f_{\mathrm{L}}=17 \mathrm{MHz}, f_{\mathrm{S}}=13.8 \mathrm{MHz}$.

Using the mode conversion method two orthogonal polarized shear $S_{\perp}$ and $S_{=}$waves were obtained from two $L$ wave transducers. This probe, simultaneously producing one longitudinal and two shear waves was used for on-line polymer injection moulding process diagnostics [17].

Longitudinal and shear waves simultaneously can be transmitted and received by small piezoceramic transducers. Barium titanate transducers, smaller in dimensions than the wavelengths of elastic waves in solids $(1 \div 3 \mathrm{~mm}$ thickness, $1 \div 3 \mathrm{~mm}$ in diameter) transmit simultaneously $L, S$ and surface waves of ultrasonic frequencies when subjected to an electrical pulse [19]. Directivity patterns of these transducers were investigated.

\section{Dual mode PZT transducers}

PZT piezoceramic is the most used piezoelectric material. These transducers are much requested but up to now only theoretical studies are known with a little experimental confirmation [20-23]. The aim of these 
studies was to find a proper cut of PZT piezoceramic, which can simultaneously respond to both pressure and shear waves. In these studies, all possible rotated ceramic cuts were examined by analyzing the piezoelectric properties, elastic and dielectric constants through numerical simulation and experiments. The optimal cut for simultaneous generation of $L$ and $S$ waves of equal strength was found. According to the theory, the simultaneous generation of $L$ and $S$ modes is possible only when PZT $Z$ axis is rotated with respect to the crystal $X$ or $Y$ axis. Rotation with respect to either $X$ axis or $Y$ axis does not make any difference. Equations presented in [22] confirm the fact that we can generate both longitudinal and shear waves with a single element made of PZT, once it is rotated appropriately. Calculations were provided for PZT$5 \mathrm{H}$ piezoelectric material, because it is widely used for ultrasonic probes. Variation of the coupling factor $k^{2}$ versus the crystal $Z$ axis rotation angle $\Theta$ was determined. According to the figure presented, when the crystal $Z$ axis is rotated $35.7^{\circ}$, the PZT element possesses equal efficiency in exiting each of the $L$ and $S$ waves. In practice, in the medium investigated these waves will not be equally strong, because of impedance mismatch between the PZT and the medium, which will be different for $L$ and $S$ waves. When $\Theta<35.7^{\circ}$, PZT element put more emphasis on the $L$ wave, when $\Theta>35.7^{\circ} S$-waves dominate.

These double mode PZT rotated piezoelements have advantage over mode conversion transducers, as $L$ and $S$ waves propagate in one beam, along the same path, what may have a decisive influence in some cases.

Information regarding the properties of various rotations of poled PZT-5A is presented in [21]. Experimental values for $45^{\circ}$ and $60^{\circ}$ rotated elements were compared with theoretical values.

Analyzing the literature data about dual mode PZT rotated piezoelements, we can conclude that most information concerns theoretical analysis and there is a lack of experimental verification.

Therefore, we have decided to develop manufacturing technology of dual mode PZT piezoelements in usual ultrasonic laboratory conditions and their optimization for real experimental requirements.

\section{Manufacturing of a dual mode PZT piezoelement}

According to the theory $[20,22,23]$, this piezoelement can be manufactured as rotated $Z$ - cut from a large thick PZT block (Fig. 1).

In Fig. $1 Z$ axis is rotated with respect to the crystal $X$ axis. The same result will be if the rotation would be with respect to the $Y$ axis. Actually, we don't know precisely where in the rectangular PZT block, and especially PZT disc, these axes are. Thus the main requirement is the value of the inclination angle $\Theta$.

Indeed, the inclination angle of the surface of the dual mode piezoelement with respect to the surface of the initial PZT block is the same as the cut angle $\Theta$.

The first experiments were provided with the cut angle $\Theta=45^{\circ}$, a thin disc diamond saw was used for this procedure. Initially, piezoelement thickness was $0.5 \mathrm{~mm}$. Later the piezoelements were lapped to the smaller thickness, depending on the required frequencies $f_{\mathrm{L}}$ and $f_{\mathrm{S}}$.

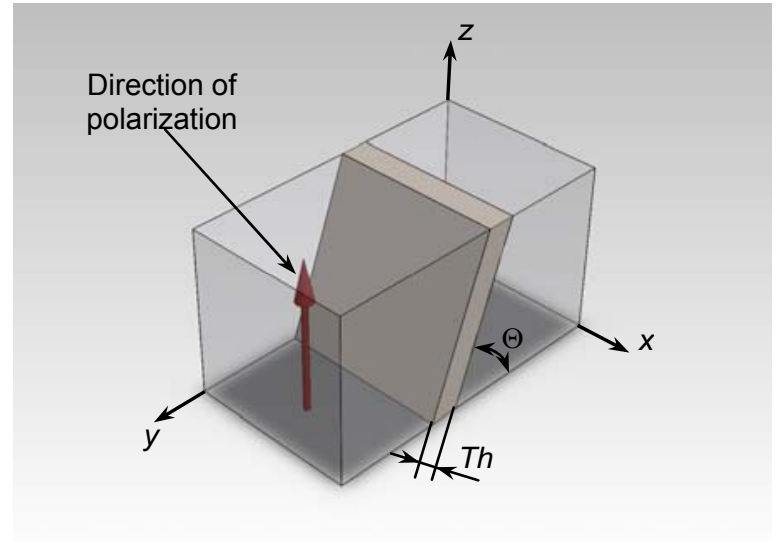

Fig. 1. Rotated $Z$ - cut dual mode $L / S$ transducer; $\Theta$ - cut angle, $T h$ piezoelement thickness.

During the lapping, piezoelements were bonded onto the precise flat surface with cyanocrylate based fast-acting adhesive. Both sides of the piezoelement are lapped in two steps, consecutively. It is necessary to achieve uniform thickness of the piezoelement in the whole its area. For that purpose a special precise device was manufactured, allowing to fix the necessary thickness in advance. After lapping, the piezoelements are removed from the flat substrate with acetone in an ultrasonic bath. Electrodes are made chemically in electroless nickel (EN) coating bath. At first the sensibilization, activation and reduction procedures were carried out for the coating of the piezoelements. After all these pre-treatments operations the samples are entered into the electroless EN plating bath. The composition of the bath is given in Table 1 .

Table 1. Chemical composition of electroless Ni-P plating

\begin{tabular}{|l|l|l|}
\hline Chemical & Formula & Concentration \\
\hline $\begin{array}{l}\text { Nickel(II) chloride } \\
\text { hexahydrate }\end{array}$ & $\mathrm{NiCl}_{2} \times 6 \mathrm{H}_{2} \mathrm{O}$ & $40-50 \mathrm{~g} / 1$ \\
\hline Ammonium chloride & $\mathrm{NH}_{4} \mathrm{Cl}$ & $45-55 \mathrm{~g} / 1$ \\
\hline Sodium citrate & $\mathrm{Na}_{3} \mathrm{C}_{6} \mathrm{H}_{5} \mathrm{O}_{7} \times 5.5 \mathrm{H}_{2} \mathrm{O}$ & $40-50 \mathrm{~g} / 1$ \\
\hline Sodium hypophosphate & $\mathrm{NaH}_{2} \mathrm{PO}_{2} \times \mathrm{H}_{2} \mathrm{O}$ & $10-20 \mathrm{~g} / 1$ \\
\hline
\end{tabular}

The temperature for the reaction process of plating must be in the interval $80 \div 88^{\circ} \mathrm{C}$. Its duration was $7 \mathrm{~min}$ and $1 \mu \mathrm{m}$ electrode thickness was achieved. For a better soldering, additionally $2 \div 3 \mu \mathrm{m}$ of $\mathrm{Ag}$ are covered electrochemically; typical cyanide silver plating solution was applied. After the manufacturing, the piezoelement was tested and $L$ and $S$ antiresonant frequencies were determined (Fig. 2).

At the $45^{\circ}$ cut angle the $S$ wave resonance $(17 \mathrm{MHz})$ was stronger than the $L$ wave $(35 \mathrm{MHz})$ (Fig. 3). This experimental result confirms the theoretical conclusions.

Contrarily, at the $\Theta=30^{\circ}$ cut angle, the $L$ wave resonance is stronger (Fig. 4).

The angle $\Theta=36^{\circ}$ with equal sensitivities of $L$ and $S$ waves was found experimentally (Fig. 5). Incredibly, it perfectly coincides with the theoretical value $35.7^{\circ}$ [20-23]. The angle $\Theta=36^{\circ}$ was determined independently of the theoretical conclusions. 


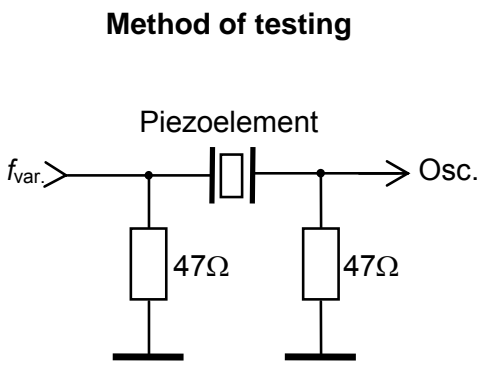

Fig. 2. Dual mode piezoelement impedance testing method

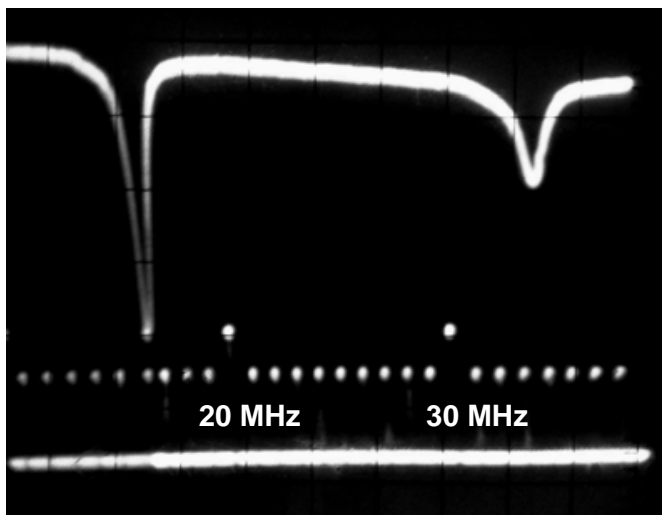

Fig. 3. At the cut angle $\Theta=45^{\circ} S$ wave resonance $(17 \mathrm{MHz})$ is stronger than the $L$ wave ( $35 \mathrm{MHz}$ ). Piezoelement thickness is $64 \div 65 \mu \mathrm{m}$

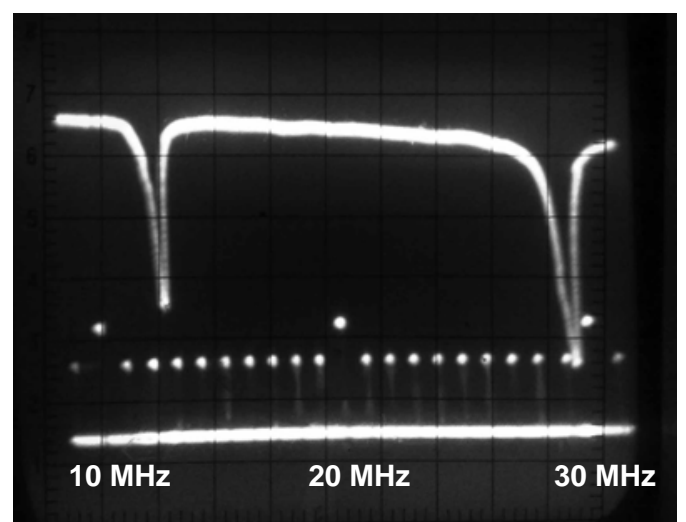

Fig. 4. At $\Theta=30^{\circ}$ cut angle the $L$ wave resonance is stronger $\left(f_{\mathrm{s}}=12.5 \mathrm{MHz}, f_{\mathrm{L}}=29 \mathrm{MHz}\right)$. Piezoelement thickness is about $70 \mu \mathrm{m}$.

In these impedance measurements the piezoelement thickness must be precisely the same in the whole its area Else, different sites of the piezoelement will be characterized by different frequencies and the resonance peaks will be distorted. The $L$ wave resonance is especially sensitive to this distortion, as its frequency is higher (Fig. 6).

\section{Experiments}

The piezoelement operating frequencies decrease after it's soldering to a substrate. The rate of this decrease depends on the substrate impedance and bonding method. In our experiments the piezoelements were soldered.



Fig. 5. At the cut angle $\Theta=36^{\circ}$ piezoelement sensitivities (peak amplitudes) of $L$ and $S$ waves are equal. Here piezoelement thickness is $104 \mu \mathrm{m}$, thickness variation is within $1 \mu \mathrm{m}$, $f_{\mathrm{L}}=21 \mathrm{MHz}, f_{\mathrm{S}}=9 \mathrm{MHz}$.



Fig. 6. Distortion of resonance peaks in the case of non-uniform thickness of the piezoelement: thickness $T h=100 \mu \mathrm{m}$; $\Delta T h=10 \%$.

(solder $60 \mathrm{Sn} 40 \mathrm{~Pb}, T=188{ }^{\circ} \mathrm{C}$ ) to the stainless steel ( $Z=45$ MRayl) waveguides and bodies. Thus piezoelements were highly damped and the significant decrease of the frequencies must be expected. For easy soldering stainless steel was electroplated with $\mathrm{Ni}$ (solution for stainless steels) and Ag. When the $70 \mu \mathrm{m}$ thickness piezoelement was soldered to the stainless steel, the $L$ wave frequency decreased from $29 \mathrm{MHz}$ to $21 \mathrm{MHz}$, the $S$ wave from $12.5 \mathrm{MHz}$ to $6.5 \mathrm{MHz}$. For a thinner $45 \mu \mathrm{m}$ piezoelement this decrease was even larger, more than twice: $47 \mathrm{MHz} \rightarrow 19 \mathrm{MHz}(L)$ and $21 \mathrm{MHz} \rightarrow 9 \mathrm{MHz}(S)$.

The first practical operation of the piezoelements was investigated when they were soldered to the stainless steel rods with the diameter $10 \mathrm{~mm}$, and the length $\mathrm{h}=10 \mathrm{~mm}$ or $15 \mathrm{~mm}$. As $L$ and $S$ wave frequencies are always different, their optimal excitation requires various durations of the excitation pulse.

When the $36^{\circ}$ rotated PZT-401 ("Morgan") double mode $\varnothing 5 \mathrm{~mm} 90 \mu \mathrm{m}$ thickness piezoelement was soldered to the $10 \mathrm{~mm}$ rod, the observed $L$ and $S$ wave pulse responses (back reflections) are shown in Fig. 7.

The $L_{1}$ and $S_{1}$ are the first back reflections of $L$ and $S$ waves, the $L_{2}$ is the second back reflection of $L$ waves. $S_{1}$ and $L_{2}$ nearly interfere due to the fact, that the $S$ wave velocity is almost a half of the $L$ wave velocity: 
$c_{\mathrm{S}}=3.13 \mathrm{~mm} / \mu \mathrm{s}, \quad c_{\mathrm{L}}=5.77 \mathrm{~mm} / \mu \mathrm{s}$. The pulses don't depend on the piezoelement shape - disc or rectangular. When the excitation pulse was optimal for $L$ waves (40 ns), the best signals $L_{1}$ and $L_{2}$ were observed, the $S_{1}$ was reasonably good. When excitation was optimal for $S$ waves (80 ns), the signal $S_{1}$ increased, but $L_{1}$ and $L_{2}$ became distorted. Thus simultaneous measurements can be provided with $40 \mathrm{~ns}$ excitation. At lower frequencies (thicker piezoelements) the signals will have larger durations, so, in a shorter body (e.g. $5 \mathrm{~mm}$ ), the reflections $S_{1}$ and $L_{2}$ will overlap each other. Contrarily, in a larger $15 \mathrm{~mm}$ body these signals are even more separated (800 ns).

Dual mode piezoelements from various PZT piezoceramics were investigated when soldered to similar steel rods. Pz27, Pz29 ("Ferroperm"), CTS-19 (Russian) showed similar operation as "Morgan". The Pz29 piezoelement is very sensitive but has a lower Curie temperature; it can't be soldered with $60 \mathrm{Sn} 40 \mathrm{~Pb}$ solder, the lower melting temperature is necessary.
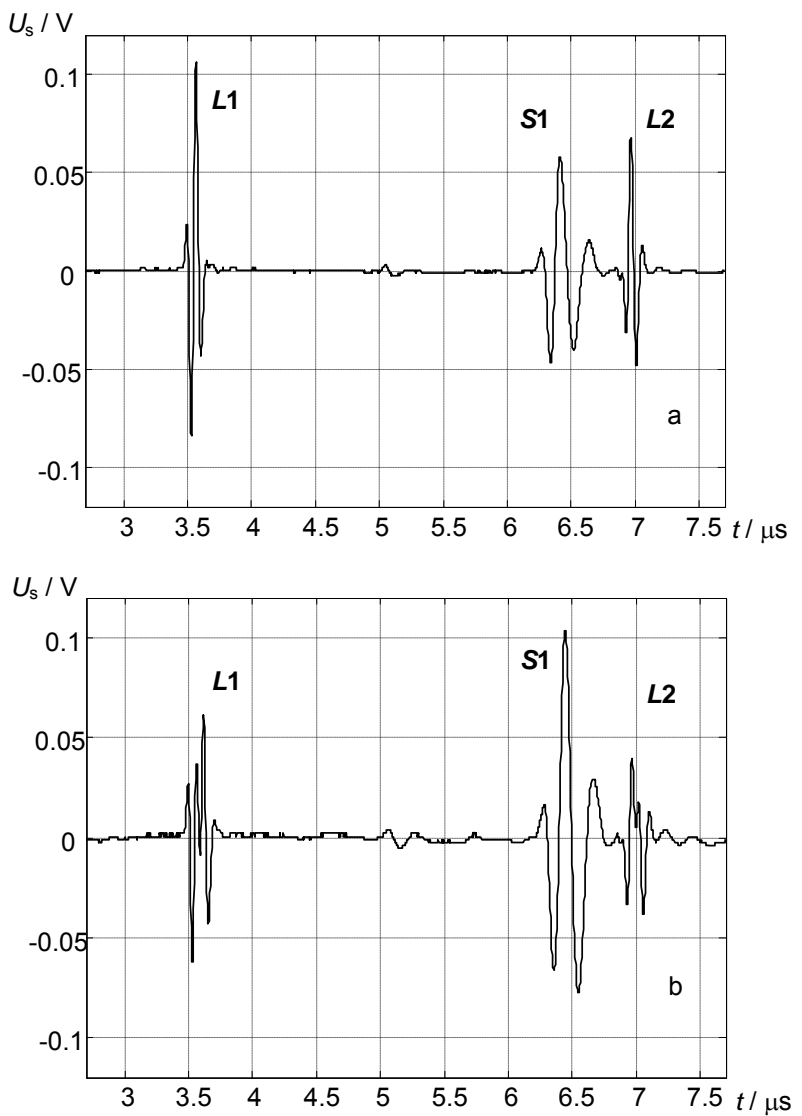

Fig. 7. $L$ and $S$ wave reflections in a steel $\operatorname{rod}(010 \mathrm{~mm}, h=10 \mathrm{~mm})$ : a - excitation pulse duration $40 \mathrm{~ns}, \mathrm{~b}$ - duration $80 \mathrm{~ns}$. Here $L_{1}$ and $S_{1}$ are the first back reflections of $L$ and $S$ waves, $L_{2}$ is the second back reflection of $L$ waves.

Measuring bodies with dual mode waves may have different geometry. It is routine, that such rods have a step near the end (Fig. 8a) for the temperature measurement possibility [1]. If this end part of a smaller diameter is long, it may serve as well as a load or stress sensor (Fig. $8 b)$.

In such experiments it is requested that the amplitudes of the necessary signals would be of similar amplitudes. It can be achieved coordinating the body geometry, the cut angle $\Theta$ and piezoelement dimensions. In a short $17 / 15$ body (Fig. 8a) the piezoelement diameter is $6 \mathrm{~mm}$, it is situated in the centre, its $\Theta=36^{\circ}$. Wave reflections in this body are shown in Fig. 9.

Both $L$ wave reflections, $L_{15}$ and $L_{17}$, are ideally identical. $S$ wave reflections amplitudes $S_{15}$ and $S_{17}$ differ; more, the second reflections $L_{15-2}$ and $L_{17-2}$ interfere with $S_{15}$ and $S_{17}$. This can be evaded modifying the body geometry. A long body (Fig. 8b) has its specifics, as in a small diameter part due to a waveguide propagation

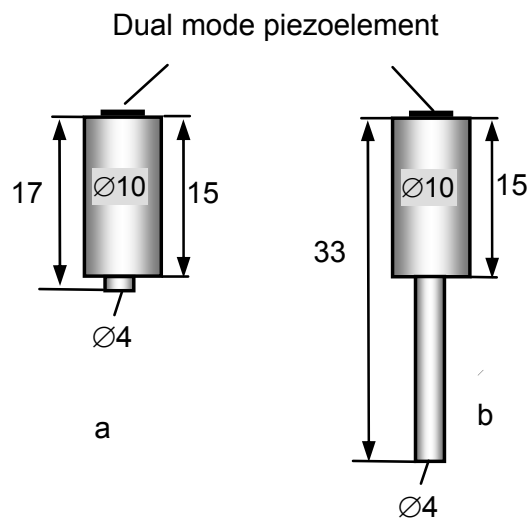

Fig. 8. Two measurements bodies used for the investigation of double mode wave propagation

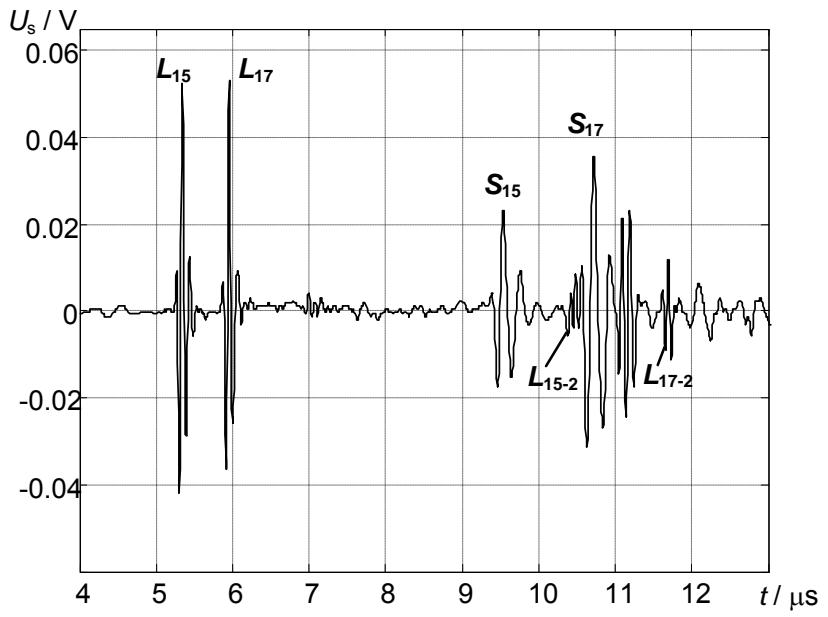

Fig. 9. Dual mode wave reflections in a short measurement body (17/15), Fig.8a

spurious signals are observed. They can be eliminated if the cylindrical surface is threaded; thread parameters must correlate with the $\mathrm{L}$ and $\mathrm{S}$ wavelength in the steel. Thread period $0.22 \mathrm{~mm}$ demonstrated good elimination of these spurious signals. Additionally, piezoelement dimensions were modified: better $\mathrm{S} / \mathrm{N}$ results demonstrated $2 \times 5 \mathrm{~mm}$ piezoelement, appropriately centered. With this piezoelement $L_{15}, S_{15}, L_{33}$ and $S_{33}$ reflections are perfectly registered (Fig. 10).

Better results (larger signal amplitudes and $\mathrm{S} / \mathrm{N}$ ratios) are optimized for " $15 \mathrm{~mm}$ " (step) and "33 $\mathrm{mm}$ " (end) reflections. For example, $L_{33}$ increased from $16 \mathrm{mV}$ (large piezoelement $4 \times 7 \mathrm{~mm}$ ) to $183 \mathrm{mV}$ (its central disc part $\varnothing 2.5 \mathrm{~mm}$ ). For these conditions, $S_{33}$ increased from $58 \mathrm{mV}$ to $283 \mathrm{mV}$. The same phenomenon concerns $L_{15}$ and $S_{15}$ 
reflections. If a lateral $1.5 \mathrm{~mm} \times 3 \mathrm{~mm}$ part of the large $4 \mathrm{~mm} \times 7 \mathrm{~mm}$ piezoelement was used, $L_{15}$ signal increased from $38 \mathrm{mV}$ to $156 \mathrm{mV}$, for $S_{15}$ signal from $24 \mathrm{mV}$ to $115 \mathrm{mV}$. In this body we escaped from the problem of $L$ wave multiple reflection disturbing influence on the $S$ wave signal; amplitudes can be changed modifying the cut angle $\Theta$, body geometry and especially piezoelement dimensions. So the solution is flexible. After this optimization signal amplitudes reached $400 \mathrm{mV}$ at $10 \mathrm{~V}$ excitation pulse, the signal to noise ratio $\mathrm{S} / \mathrm{N}>100$.
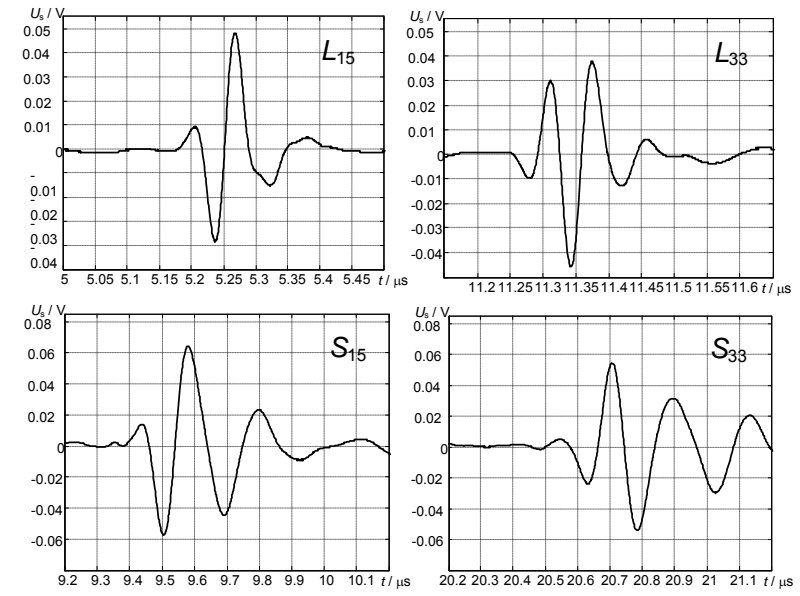

Fig. 10. Dual wave reflections in a long measurement body (8b)

Soldering of these PZT piezoelements to the steel body is very reliable if accurately made. Reflections in the $10 \mathrm{~mm}$ rod were observed in the temperature range $20-$ $160^{\circ} \mathrm{C}$. The rod was uniformly heated when immersed in silicone oil. The amplitudes of the reflected $L$ and $S$ signals consistently decreased in this temperature range (Fig. 11), but after cooling fully restored.

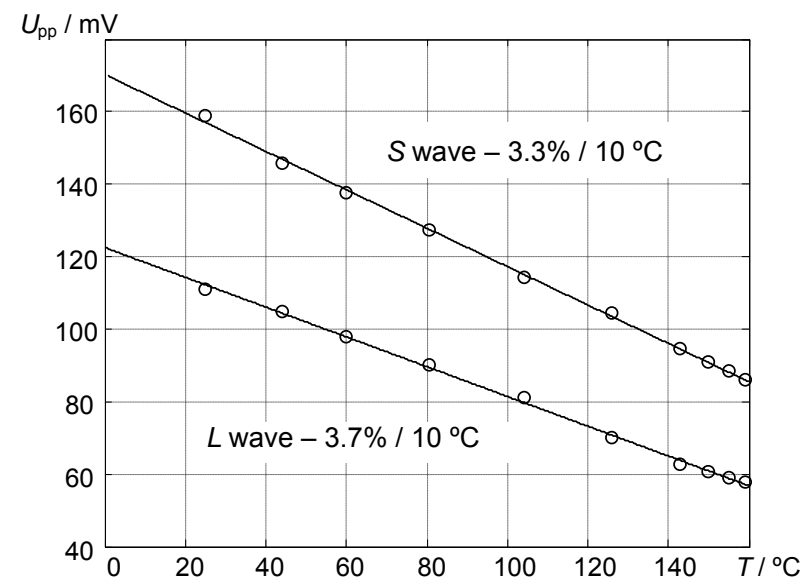

Fig. 11. The amplitudes of $L$ and $S$ signals decrease as the temperature grows

Thus the piezoelement can operate up to $160{ }^{\circ} \mathrm{C}$ reliably. If the solder would be with a higher melting point, higher operation temperatures are expected (up to $250^{\circ} \mathrm{C}$, as the Curie temperature is $T_{\mathrm{C}}=350{ }^{\circ} \mathrm{C}$ for this $\mathrm{Pz} 27$ ). Finally, the delay times of the $L$ and $S$ wave reflections were measured as a function of an axial load. For that purpose the tip of the body was pressed via Teflon layer and the pressure was measured directly in $\mathrm{MPa}$.

For a better accuracy, the time differences were measured:

$$
\begin{aligned}
& \Delta t_{\left(S_{33}-L_{33}\right)}=\varphi(P) ; \\
& \Delta t_{\left(L_{33}-L_{15}\right)}=\varphi(P) .
\end{aligned}
$$

For both cases good linear dependencies were obtained (Fig. 12 and 13). These are the initial data for calculation of stresses according to the literature formulae [1].



Fig. 12. Time difference $\Delta t\left(s_{33}-L_{33}\right)$ as a function of an axial load in a long measurement body (Fig. 8b)

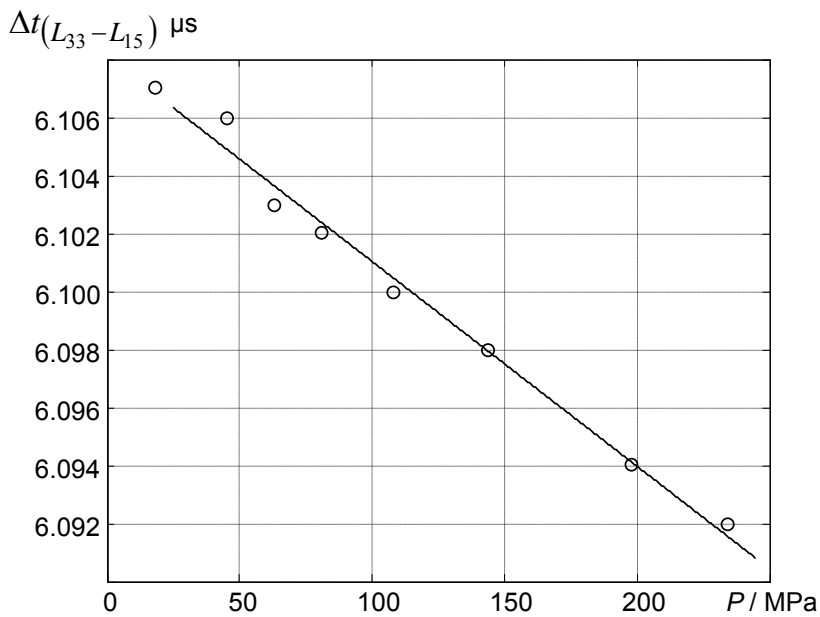

Fig. 13. Time difference $\Delta t\left(L_{33}-L_{15}\right)$ as a function of an axial load in the same body (Fig. 8b).

\section{Conclusions}

Dual mode longitudinal and shear wave pjezoelements were manufactured from a thick PZT block using rotated cut method.

At the $36^{\circ}$ cut angle equal efficiency of longitudinal and shear waves was obtained. By variation of the cut angle one or another mode can be emphasized. The piezoelement thicknesses were in the range 45-100 $\mu \mathrm{m}$. 
Electrodes were made chemically in electroless nickel (EN) coating bath. Additionally electrodes were covered by $2-3 \mu \mathrm{m}$ of silver electrochemically. Such piezoelements can be soldered perfectly with $60 \mathrm{Sn} 40 \mathrm{~Pb}$ solder to steel substrates. The piezoelement operation in a temperature range $20-160^{\circ} \mathrm{C}$ was good. Axial load experiments up to $234 \mathrm{MPa}$ were provided and corresponding linear the timeof-flight dependencies were determined for longitudinal and shear waves. Experiments showed eligible performance of dual mode PZT ultrasonic transducers.

\section{Acknowledgements}

The authors wish to thank dr. A. Vladišauskas, dr. G. Seniūnas and Dr. E. Žukauskas for their assistance in these experiments.

\section{References}

1. Wu K.-T., Kobayashi, M., Jen C.-K. Making screws as axial load and temperature probes using integrated ultrasonic transducers. 2008. 2008 IEEE International Ultrasonic Symposium Proceedings. P. 418421 .

2. http://en.wikipedia.org/wiki/Crystal_oscillator.

3. Bandey H. L., Cernosek R. W., Lee W. E., Ondrovic L. E. Blood rheological characterization using the thickness-shear mode resonator. Biosensors and Bioelectronics. 2004. Vol. 19. Issue 12. P. 1657-1665.

4. Boston Piezo-Optics Inc. Triple-Mode Transducer Crystals. http://www.bostonpiezooptics.com/

5. Cheng-Kuei Jen. Ultrasonic transducers for simultaneous generation of longitudinal and shear waves. J. Acoust. Soc. Am. 1988. Vol. 84, No. 1. P. 26-29.

6. Rouvaen J. M., Menhaj-Rivenq A., Logette P., Goutin P., Haine F. Simultaneous generation of longitudinal and shear bulk ultrasonic waves in solids. J. Phys. D: Applied Physics. 2000. Vol. 33. P. $1287-$ 1297.

7. Rouvaen J. M., Menhaj-Rivenq A., Logette P., Goutin P., Haine F. On the design of multimode ultrasonic transducers for acoustooptic correlation applications. J. Phys. D: Applied Physics. 2000. Vol. 33. P. 3041-3052.

8. Cheng-Kuei Jen, Kondepudy Sreenivas, Mike Sayer. Ultrasonic transducers for simultaneous generation of longitudinal and shear waves. http://www.stormingmedia.us/89/8966/D896623.html

9. Martin P. M., Good M. S., Johnston J. W., Posakony G. J., Bond L. J., Crawford S. L. Piezoelectric films for 100-MHz ultrasonic transducers. Thin Solid Films. 2000. Vol. 379. Issues 1-2. P. 253 258.

10. Khoder A., Bonjour E., Couach M. Simultaneous two-mode ultrasonic excitation, by means of disoriented CdS layers. J. Phys. D: Appl. Phys. 1980. Vol. 13. P. 2233-6.

11. Takahiko Yanagitani, Takuya Matsuo, Mami Matsukawa, Yoshiaki Watanabe. Thin film stack transducer for simultaneous generation of longitudinal and shear waves at same frequency. 2007 IEEE Ultrasonic Symposium. P. 1874-1877.

12. Chigarev N., Zinin P., Li-Chung Ming, Amulele G., Bulou A., Gusev V. Laser generation and detection of longitudinal and shear acoustic waves in a diamond anvil cell. Applied Physics Letters. 2008. Vol. 93. P. 181905-1 $\div 181905-3$.

13. J. van Steveninck. Apparatus for simultaneous determination of longitudinal and shear velocities under pressure. J. Sci. Instrum. 1967. Vol. 44. P. 379-381.
14. Jen, C.-K. Ono Y. Kobayashi M. High temperature integrated ultrasonic shear wave probes. Applied Physics Letters. 2006. Vol. 89. Issue 18. P. 183506-183506-3. IEEEXplore. Digital library. http://ieeexolore.ieee.org/Xplore/defdeny.jsp?url

15. Ono Y., Kobayashi M. High temperature integrated ultrasonic shear and longitudinal wave probes. Review of Scientific Instruments. 2007. Vol. 78. P. 024903-024903-5.

16. Kobayashi M., Jen C.-K., Ono Y., Wu K.-T., Ishang S. Integrated high temperature longitudinal, shear and plate acoustic wave transducers. Japanese Journal of Applied Physics. 2007. Vol.46. P. 4688-4692.

17. Wu K.-T., Kobayashi M., Zhao L. Ultrasonic probes simultaneously producing one longitudinal and two shear waves and their potential applications. 2009. 2009 IEEE International Ultrasonic Symposium Proceedings. P. 629-632.

18. Kobayashi M., Jen C.-K. Integrated and flexible high temperature ultrasonic transducers. The $4^{\text {th }}$ International Workshop on Ultrasonic and Advanced Methods for Nondestructive Testing and Material Characterization. 2006. N. Dartmouth. MA - Proceedings published in www.ndt.net

19. Taro Anzai. Generation and detection of ultrasonic waves in solids by small Barium titanate transducers. The research institute for scientific measurements. Tohoku University. 1959. P. 9. Library.tohoku.ac.jp/re/bitstream/...

20. Kim B. S. A $\mathrm{P} / \mathrm{S}$ mode transducer with a piezoelectric ceramic of PZT type: theory and fabrication. 1981.

21. Wickstrom S. N. Characterization of PZT-5A dual thickness mode resonators. In: Ultrasonics Symposium, 1990. Proceedings. IEEE 1990. Vol. 1. P. 577-580.

22. Yeon-Bo Kim, Yong-Rae Rho. Fabrication of dual-mode ultrasonic transducer using PZT. Journal of the Korean Institute of Electrical and Electronic Material Engineers. 2002. Vol. 15. No. 10. P. 914920.

23. Yeon-Bo Kim, Yongrae Roh, Hyo-Duk Nam. Fabrication of dualmode ultrasonic transducers with PZT piezoelectric ceramics. Journal of the Korean Institute of Electrical and Electronic Material Engineers. 1995. Vol. 8. No. 5. P. 572-579.

A. Voleišis, R. Kažys, B. Voleišienè, R. Šliteris

Išilginių ir skersinių ultragarso bangų generavimas: literatūros apžvalga, švino-cirkonio-titanato (PZT) pjezoelementų sukūrimas ir eksperimentai

Reziumé

Apžvelgiami žinomi išilginių ir skersinių bangų generavimo pjezokeitikliai: kvarco ir ličio niobato pjezoelementai, kampu orientuoti $\mathrm{CsS}$ ir $\mathrm{ZnO}$ pjezosluoksniai. Daugiausia dèmesio skiriama PZT keramikai. Aptariami žinomi teorinių tyrimų rezultatai. Išilginių ir skersinių bangų dviejų modų PZT keitiklių gamybos technologija sukurta taikant skirtingus PZT pjūvio kampus ir pjezoelementų storius. Pjezoelementu elektrodai gaunami cheminio nikeliavimo būdu paskui jie elektrochemiškai padengiami sidabru. Eksperimentiškai nustatyta, kad dviejų modų pjezoelementams vienodai tinka ịvairių tipų PZT keramika. Iš impedanso matavimų nustatyti išilginių ir skersinių bangų rezonansiniai dažniai. Tyrinètų pjezoelementu storiai buvo $45-100 \mu \mathrm{m}$. Esant $36^{\circ}$ pjūvio kampui, gaunamos vienodo intensyvumo išilginès ir skersinès bangos. Šie pjezoelementai buvo lituojami prie plieno užlaikymo linijos ir specialios formos pavyzdžių. Matavimai buvo atliekami esant iki $160^{\circ} \mathrm{C}$ temperatūrai ir iki $234 \mathrm{MPa}$ ašiniam slègiui. Eksperimentais patvirtintas geras dviejų modų pjezoelementų darbas.

Pateikta spaudai 20110314 